\title{
Effect of Rice Husk Ash on High-Temperature Mechanical Properties and Microstructure of Concrete
}

DOI: $10.15255 /$ KUI.2016.054 KUI-13/2017

Preliminary communication Received December 22, 2016 Accepted February 18, 2017

\author{
W.-H. Wang, ${ }^{\text {a,b }}$ Y.-F. Meng, ${ }^{\text {a,b* }}$ and D.-Z. Wang ${ }^{a}$ \\ a School of Civil Engineering and Hydraulic Engineering, Ningxia University, \\ Yinchuan 750 021, Ningxia, P.R. China \\ b Yinchuan Energy Institute, Yinchuan 750 105, Ningxia, P.R. China
}

This work is licensed under Creative Commons Attribution 4.0

\begin{abstract}
\| Abstract
Effects of rice husk ash (RHA) on the strength and temperature resistance of concrete were investigated. Different amounts of cement in concrete were replaced by RHA and fly ash (FA), used as mineral admixtures, under the condition of a constant binder content. The compressive strength and temperature resistance were tested at different temperatures. The results show that mixing concrete with the appropriate amounts of RHA can improve its compressive strength. At $800{ }^{\circ} \mathrm{C}$, the strength is $50 \%$ greater than that of normal concrete (NC). Thus, RHA can improve the strength and temperature resistance of concrete.
\end{abstract}

\| Keywords

Rice husk ash, concrete, compressive strength, high temperature

\section{Introduction}

With the emergence of high-rise buildings, fire prevention has become particularly important. In the event of a fire, the physical and mechanical properties of the aggregates of concrete structures and cement-gelled materials are degraded, resulting in a sharp drop in the load-bearing capacity of structures, which can even cause collapse of the building in serious cases. Therefore, the study of the mechanical properties of concrete under high temperature has great significance.

Normally, rice husk is piled in open air or occasionally discarded or burnt in the fields, which results in serious environmental pollution. The burning of rice husk can also cause fires. The highly active silica fume (SF) plays a significant role in the preparation of high-strength and high-performance concrete. However, because of the limited availability of SF, it is too expensive for many practical engineering applications. The use of highly active RHA to replace SF as the admixture for concrete can not only improve the performance of concrete and reduce costs, but also reduce the environmental pollution caused by rice husk.

RHA, the product of burning raw rice husk, has a greater content of $\mathrm{SiO}_{2}$ by more than $90 \%$. Compared with conventional mineral admixtures such as fly ash (FA) and slag, RHA has a huge specific surface area and high activity, which is preferable for active mineral admixture. ${ }^{1}$ Studies on the chemical composition, microstructure, and pozzolanic activity of active RHA have shown that the root cause of the high activity of RHA is its high content of amorphous $\mathrm{SiO}_{2}$ components and nanoscale $\mathrm{SiO}_{2}$ gel par-

*Corresponding author: Yunfang Meng, Ph.D.

e-mail address: 2979526409@qq.com ticles, as well as micropores. ${ }^{2}$ Some researchers in China and abroad have also studied the application of RHA to HPC, and their results showed that the addition of active RHA greatly promotes the hydration reaction of cement, improves the microstructure of concrete, and increases the strength of concrete. ${ }^{3-5}$ In addition, concrete mixed with RHA showed good durability properties in terms of frost resistance, impermeability, and resistance to chemical attack. ${ }^{6-9}$ This suggests that RHA can potentially be a type of active mineral admixture. Furthermore, this application of RHA contributes to the sustainable development of environmental resources.

The chemical composition and properties of RHA are different in different regions and with different experimental processes. However, there is limited research on the high-temperature properties of RHA in China. Thus far, the changes of the high-temperature mechanical properties and internal microstructures of concrete mixed with local RHA have not been clarified. Therefore, in this study, the mechanical properties and internal microstructures of concrete produced with local materials were studied at five different temperatures. Furthermore, the strength reduction law of high-temperature concrete mixed with RHA was explored.

\section{Experimental part}

\subsection{Materials}

The RHA used in this study was collected after burning raw rice husk in a boiler at $600{ }^{\circ} \mathrm{C}$ for approximately $60 \mathrm{~min}$. The XRD pattern of RHA is shown in Fig. 1, and Table 1 summarizes its chemical composition. As shown in the $\mathrm{X}$-ray pattern in Fig. 1, the main chemical components 
of $\mathrm{RHA}$ are $\mathrm{SiO}_{2}, \mathrm{CaO}, \mathrm{Fe}_{2} \mathrm{O}_{3}$, and $\mathrm{Al}_{2} \mathrm{O}_{3}$. Characteristic peaks of crystalline-phase $\mathrm{SiO}_{2}$ appear at $2 \theta=22.0^{\circ}$, $28.4^{\circ}, 31.5^{\circ}$, and $36.1^{\circ}$, which correspond to lattice planes of (101), (111), (102) and (200). Analysis with Jade indicates that $28.13 \%$ of RHA is crystal $\mathrm{SiO}_{2}$, whereas $55.87 \%$ of $\mathrm{SiO}_{2}$ is in the amorphous state. It is worth noting that amorphous $\mathrm{SiO}_{2}$ has very high activity. The chemical composition of grade I FA, used in some concrete samples in this study, is presented in Table 1. SEM images of RHA and FA are shown in Fig. 2.

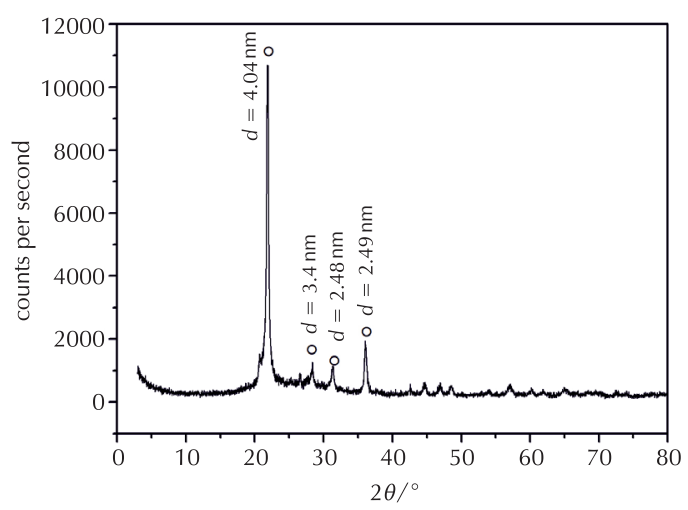

Fig. 1 -XRD pattern of rice husk ash

The RHA particles have irregular edges, and their size ranges from several micrometers to tens of micrometers. Figs. 2(a) and (b) show that there are many small particles around large particles. The particle size distributions of RHA are shown in Fig. 3. It can be found that the RHA content with a particle size of $45 \mu \mathrm{m}$ and below is greater than $90 \%$. Thus, RHA is easily ground, and small particles are easily adsorbed on the surface of larger particles. Fig. 2(c) shows that FA, which is commonly used to produce high-performance concrete (HPC), consists of spherical particles. Owing to the spherical particles of FA and its activity, FA increases the workability and long-term compressive strength of concrete. ${ }^{10-12}$

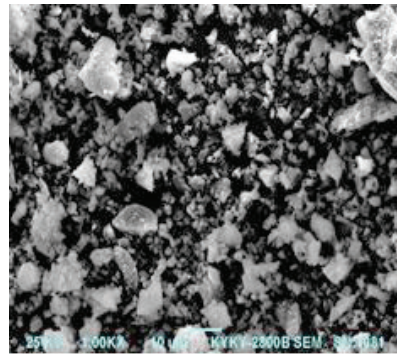

(a) $1000 \times$

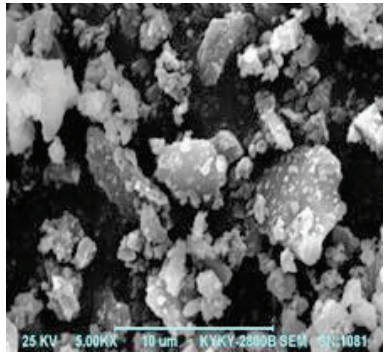

(b) $5000 \times$

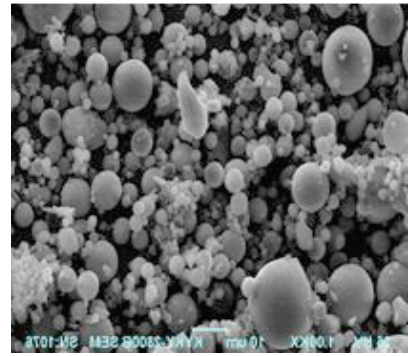

(c) $1000 \times$

Fig. 2 -SEM images of (a) and (b) rice husk ash, and (c) fly ash

Table 1 -Mineral composition of the cement

\begin{tabular}{c|c|c|c}
\hline \multicolumn{4}{|c}{$w / \%$} \\
\hline $\mathrm{C}_{3} \mathrm{~S}$ & $\mathrm{C}_{2} \mathrm{~S}$ & $\mathrm{C}_{3} \mathrm{~A}$ & $\mathrm{C}_{4} \mathrm{AF}$ \\
\hline 56.90 & 21.16 & 4.83 & 17.11 \\
\hline
\end{tabular}

The cement $(\mathrm{C})$ used in the concrete is ordinary Portland cement with the strength grade of 42.5 complying with the Chinese National Standard GB 175-2007 of Horse Racing brand from Ningxia in China. Its 28-d compressive strength is $45.2 \mathrm{MPa}$, and its flexural strength is $8.3 \mathrm{MPa}$. Table 1 shows the mineral composition of the cement. The content of $\mathrm{C}_{3} \mathrm{~S}$ and $\mathrm{C}_{2} \mathrm{~S}$ is greater than $78 \%$. The physical properties of C, FA, and RHA including chemical composition, specific gravity, and fineness are summarized in Table 2.

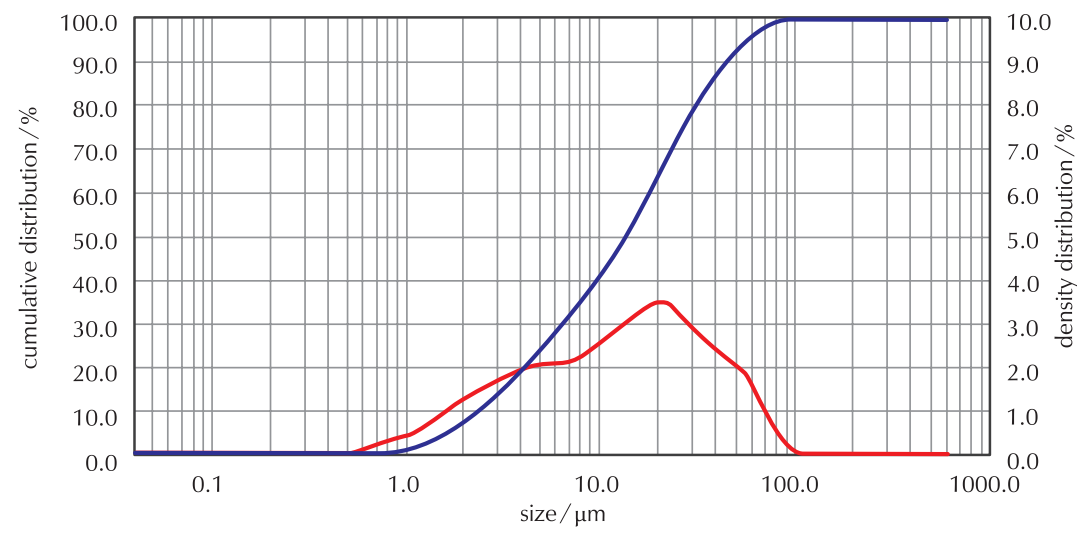

\begin{tabular}{r|c}
\hline size $/ \mu \mathrm{m}$ & cumul./\% \\
\hline 0.300 & 0.00 \\
\hline 0.800 & 0.70 \\
\hline 2.000 & 7.91 \\
\hline 10.000 & 41.70 \\
\hline 20.000 & 64.76 \\
\hline 35.000 & 83.56 \\
\hline 40.000 & 87.13 \\
\hline 42.000 & 88.35 \\
\hline 45.000 & 90.04 \\
\hline 50.000 & 92.47 \\
\hline
\end{tabular}

Fig. 3 - Particle size distribution of rice husk ash 
The coarse aggregate used in the mixture is natural coarse aggregate made of crushed limestone. Its particle-size distribution has a continuous gradation in the range of $5-25 \mathrm{~mm}$, crush index of $6.4 \%$, and mud content of $0.8 \%$. The fine aggregate used in the mixture is natural sand composed of quartz. Its fineness modulus is 2.78 , and mud content $2.1 \%$. In addition, the dosages of polycarboxylate superplasticizer (SP) used in concrete is $2 \%$ and the water-reducing rate is up to $25 \%$. The water used for mixing is drinking water.

\subsection{Mixture proportions}

In this study, the effects of admixtures including RHA and FA on the mechanical properties and microstructure of concrete were investigated after being subjected to elevated temperatures. Seven mix proportions were designed with a constant water to binder ratio of 0.30 . Cement was replaced with RHA and combined admixtures of RHA/FA by weight; the mass fraction of rice RHA is $10 \%, 15 \%$, and $20 \%$, and the fraction of FA was kept constant at $15 \%$. The designed mixture proportions of concrete are listed in Table 3. The mixture types were designed based on the type and fraction of cement replacement. For example, in R10F15, $25 \%$ C was replaced with $10 \%$ RHA and $15 \%$ FA.

\subsection{Experimental method}

High-temperature tests were conducted with cubical specimens of size $100 \mathrm{~mm}$. All the specimens were maintained under a standard curing condition $\left(20 \pm 2{ }^{\circ} \mathrm{C}\right.$ and relative humidity greater than $95 \%$ ) for 56 days. The average water content in specimens prior to testing is approximately $3-4 \%$. To avoid explosive spalling, the test had been started after drying for $72 \mathrm{~h}$ in a drying box at $100{ }^{\circ} \mathrm{C}$. The experiment was performed in a box-type resistance furnace with an average heating rate of $10{ }^{\circ} \mathrm{C}$ min $^{-1}$ which was reported by some researchers. ${ }^{13-14}$ Five test temperatures were chosen: room temperature $\left(20{ }^{\circ} \mathrm{C}\right), 200{ }^{\circ} \mathrm{C}, 400{ }^{\circ} \mathrm{C}$, $600{ }^{\circ} \mathrm{C}$, and $800{ }^{\circ} \mathrm{C}$. Except for the room-temperature test, the specimens were exposed to target temperatures for $2 \mathrm{~h}$ in the steady-state condition, because the time at the target temperature impacts concrete strength. Subsequently, the furnace was turned off, and the door of the furnace was opened. The temperature of the specimens was reduced to room temperature through natural cooling in the furnace for $24 \mathrm{~h}$. The relative humidity in the laboratory was $40 \%$ during cooling. Then, the YAW-4306 computer control universal testing machine was used to test the compressive strength of concrete; each mixture contained three samples at each temperature, and the average values were taken.

The thermal analysis instrument used was a Setsys Evolution differential scanning calorimetry (DSC) - thermogravimetric (TG) comprehensive thermal analyser manufactured by SETARAM. The DSC-TG analyses were performed at temperatures ranging from $20^{\circ} \mathrm{C}$ to $1000{ }^{\circ} \mathrm{C}$ with a heating rate of $10^{\circ} \mathrm{C} \mathrm{min}^{-1}$. X-ray diffraction (XRD) analysis was performed using the Dmax 2200PC X-ray diffractometer with a scanning range from $3^{\circ}$ to $146^{\circ}$, manufactured by Rigaku Corporation. SEM images were acquired using the scanning electron microscope KYKY2800B manufactured by KYKY. Its resolution is $10 \mathrm{~nm}$, and its magnification factor could be adjusted continuously in the range of 25-20000.

Table 2 - Main chemical composition, specific gravity and fineness of cement, FA, and RHA used

\begin{tabular}{|c|c|c|c|c|c|c|c|c|c|}
\hline & \multicolumn{6}{|c|}{$\frac{w}{\%}$} & \multirow{2}{*}{$\frac{\text { density }}{\mathrm{g} \mathrm{cm}^{-3}}$} & \multirow{2}{*}{$\begin{array}{c}\begin{array}{c}\text { Blaine } \\
\text { fineness }\end{array} \\
\mathrm{m}^{2} \mathrm{~kg}^{-1}\end{array}$} & \multirow{2}{*}{$\begin{array}{c}\text { BET } \\
\text { specific surface } \\
\mathrm{m}^{2} \mathrm{~g}^{-1}\end{array}$} \\
\hline & $\mathrm{SiO}_{2}$ & $\mathrm{Al}_{2} \mathrm{O}_{3}$ & $\mathrm{Fe}_{2} \mathrm{O}_{3}$ & $\mathrm{CaO}$ & $\mathrm{MgO}$ & $\mathrm{SO}_{3}$ & & & \\
\hline Cement & 21.08 & 5.12 & 5.31 & 65.28 & 1.01 & 1.98 & 3.19 & 335 & - \\
\hline FA & 45.0 & 26.8 & 8.53 & 7.35 & 2.84 & 2.86 & 2.55 & 650 & - \\
\hline RHA & 84.0 & 1.35 & 1.45 & 3.17 & - & 0.923 & 2.09 & - & 19 \\
\hline
\end{tabular}

Table 3 - Mix proportions for the designed mixtures

\begin{tabular}{c|c|c|c|c|c|c|c}
\hline \multirow{2}{*}{ Sample } & \multicolumn{7}{c}{ Mix proportion $/ \mathrm{kg} \mathrm{m}^{-3}$} \\
\cline { 2 - 8 } & water & cement & sand & $\begin{array}{c}\text { coarse } \\
\text { aggregate }\end{array}$ & RHA & FA & SP \\
\hline NC & 150 & 500 & 700 & 1050 & 0 & 0 & 10 \\
R10 & 150 & 450 & 700 & 1050 & 50 & 0 & 10 \\
R15 & 150 & 425 & 700 & 1050 & 75 & 0 & 10 \\
R20 & 150 & 400 & 700 & 1050 & 100 & 0 & 10 \\
R10F15 & 150 & 375 & 700 & 1050 & 50 & 75 & 10 \\
R15F15 & 150 & 350 & 700 & 1050 & 75 & 75 & 10 \\
R20F15 & 150 & 325 & 700 & 1050 & 100 & 75 & 10 \\
\hline
\end{tabular}


A field-emission scanning electron microscope, JSM7500F, manufactured by JEOL Corporation was used in this study. Its magnification factor can be adjusted continuously in the range of $20-800000$.

\section{Results and discussion}

\subsection{Influence of rice husk ash on the strength of concrete at high temperatures}

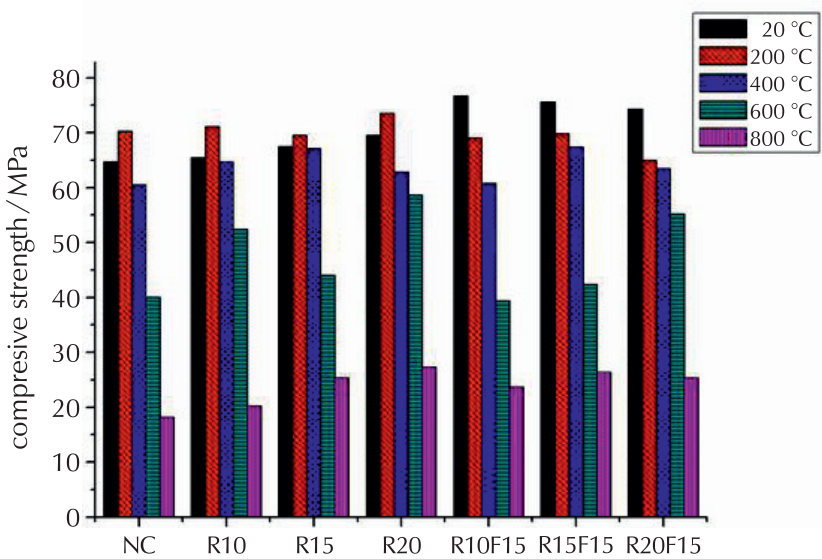

Fig. 4 - Compressive strength change at different temperatures

Generally, the strength of concrete is reduced by varying degrees at high temperature. Fig. 4 shows the variation of residual compressive strength of concrete for different temperatures. The compressive strength of RHA concrete is higher than that of $\mathrm{NC}$ at room temperature. The compressive strengths of NC, R10, R15, and R20 concrete are slightly improved at $200{ }^{\circ} \mathrm{C}$ compared to those at $20{ }^{\circ} \mathrm{C}$. This may be due to the hydration of unhydrated cement at $200{ }^{\circ} \mathrm{C}$. The hydration of cement leads to the formation of more hydrated calcium silicate (C-S-H) gel. Thus, the compressive strength of concrete is increased with the hydration. The extent of improvement in compressive strength is reduced with the increase in the RHA content. With the mixtures of $0 \%, 10 \%, 15 \%$, and $20 \%$ RHA content, the compressive strength increased by $8.7 \%, 8.6 \%, 3.1 \%$, and $5.7 \%$ respectively. The compressive strength of compound mixed RHA/FA concrete at $200{ }^{\circ} \mathrm{C}$ is lower than that at $20^{\circ} \mathrm{C}$. This is mainly due to the decrease in the content of unhydrated cement with greater RHA/FA replacement. At $200{ }^{\circ} \mathrm{C}$, the concrete suffers microstructural damage, far exceeding the strength improvement due to the high-temperature curing effect. Therefore, the compressive strength of compound mixed RHA/FA concrete is reduced at $200{ }^{\circ} \mathrm{C}$. However, the extent of compressive-strength reduction is increased with the increase in the RHA content. With $10 \%, 15 \%$, and $20 \%$ RHA content, the compressive strength is reduced by $9.9 \%, 10.3 \%$, and $12.5 \%$, respectively, relative to the sample with the lower RHA content. The compressive strength of all samples of concrete decreased at $400{ }^{\circ} \mathrm{C}$, but the extent of decrease was not high. When heated to $600{ }^{\circ} \mathrm{C}$, the compressive strength decreased significantly; in the case of $10 \% \mathrm{RHA} / 15 \% \mathrm{FA}$ concrete (R10F15), the decrease is $49 \%$. At a temperature of $800{ }^{\circ} \mathrm{C}$, the compressive strength of concrete is only $30 \%-40 \%$ of that at room temperature. However, the compressive strength of RHA concrete is higher than that of NC. The residual compressive strength of R20 is $50 \%$ greater than that of NC.

\subsection{Change of cement phase at high temperature}

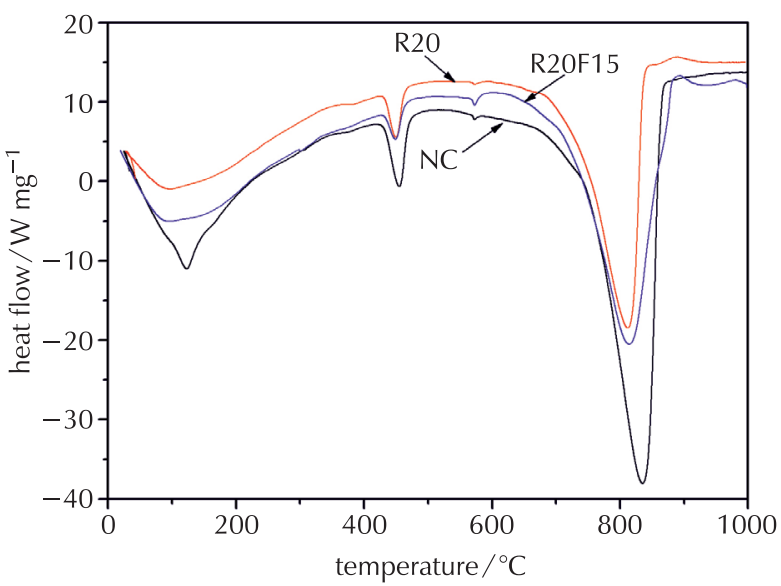

(a) DSC

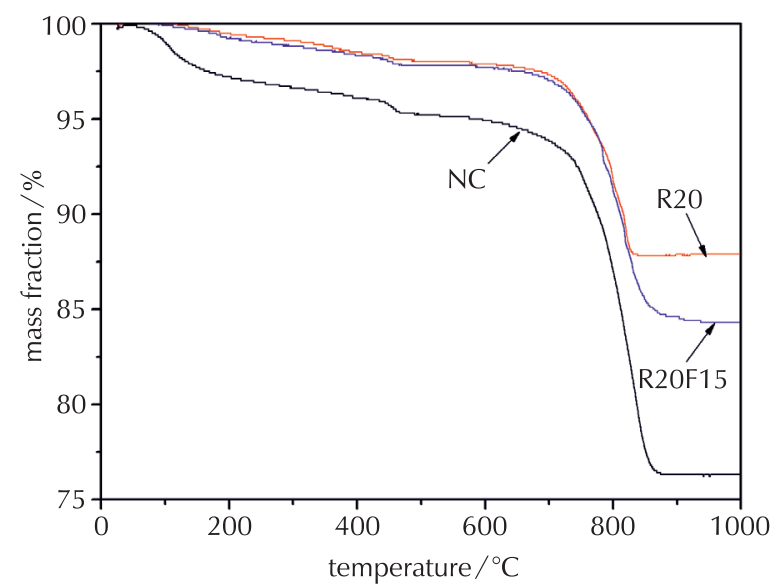

(b) TG

Fig. 5 - DSC-TG curves of cement paste

DSC and TG tests of NC, R20, and R2OF15 concrete were performed at $20-1000{ }^{\circ} \mathrm{C}$; the results are shown in Figs. 5(a) and (b), respectively. Fig. 5(a) shows an endothermic peak for the three samples between $20{ }^{\circ} \mathrm{C}$ and $1000{ }^{\circ} \mathrm{C}$. The corresponding temperature range is also consistent among the three samples. The endothermic peak of NC was the strongest with the maximum mass loss. There is an obvious endothermic peak near $120^{\circ} \mathrm{C}$ in NC. However, the curves for R20 and R20F15 are relatively smooth. Fig. 5(b) shows that the quality loss of NC is greater. The reason for the deterioration in quality is the evaporation of free water in concrete. ${ }^{15}$ The endothermic peak near $450{ }^{\circ} \mathrm{C}$ and $570{ }^{\circ} \mathrm{C}$ is caused by the decomposition of $\mathrm{Ca}(\mathrm{OH})_{2}$ and dehydra- 
tion of C-S-H gel. The deterioration of quality is clearly observed from the TG curve.

When the temperature is near $800{ }^{\circ} \mathrm{C}$, obvious endothermic peak can be seen in the DSC curve of Fig. 5(a). In the corresponding TG curve, there is a significant loss of mass, which is due to the decomposition of $\mathrm{CaCO}_{3}$. The quality losses for NC and R20 are approximately $23 \%$ and $12 \%$, respectively. Fig. 6 shows the XRD patterns of R20 at $20{ }^{\circ} \mathrm{C}, 200{ }^{\circ} \mathrm{C}, 400{ }^{\circ} \mathrm{C}, 600{ }^{\circ} \mathrm{C}$, and $800{ }^{\circ} \mathrm{C}$.

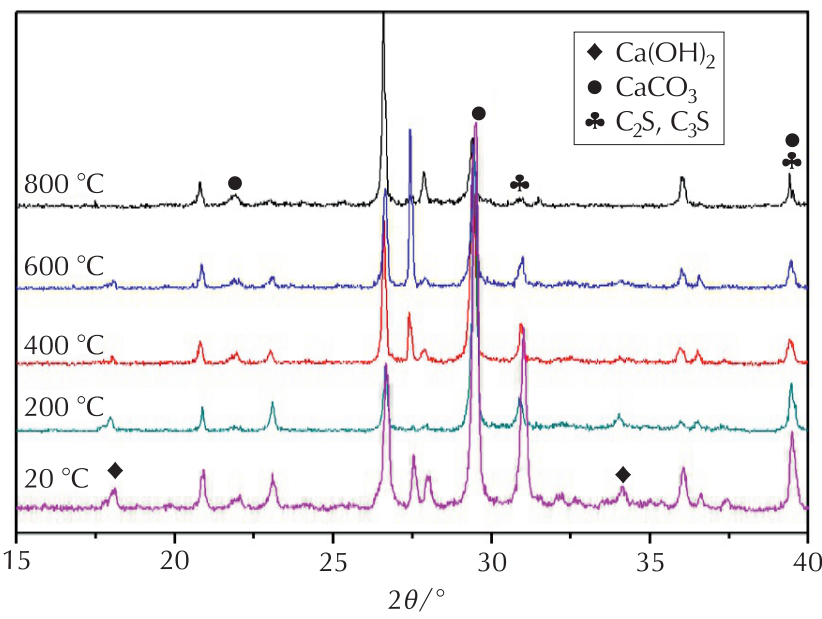

Fig. 6 - XRD patterns of R20 cement paste at different temperatures

The XRD analysis shows that, with the change of temperature, the content of crystallization products of cement stone change. From $20{ }^{\circ} \mathrm{C}$ to $400{ }^{\circ} \mathrm{C}$, the diffraction peaks of the $\mathrm{Ca}(\mathrm{OH})_{2}$ crystal planes (001) and (101) $(d=0.263$ and $0.490 \mathrm{~nm}$, respectively) decreased significantly. We can hardly observe the diffraction peak above $600{ }^{\circ} \mathrm{C}$. This shows that $\mathrm{Ca}(\mathrm{OH})_{2}$ starts to break down when heated above $400{ }^{\circ} \mathrm{C}$. At $600{ }^{\circ} \mathrm{C}$, most of the $\mathrm{Ca}(\mathrm{OH})_{2}$ has decomposed, and the C-S-H gel has been dehydrated. At $800{ }^{\circ} \mathrm{C}$, the diffraction peak of $\mathrm{CaCO}_{3}$ decreased significantly because of its decomposition. This result is consistent with the DSC-TG thermal analysis.

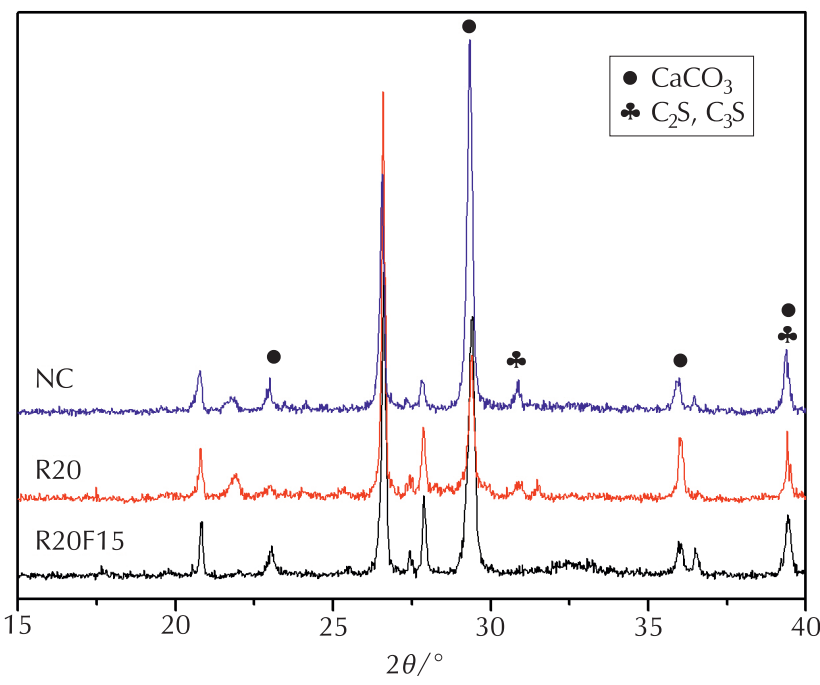

Fig. 7 - XRD curve of cement paste at $800^{\circ} \mathrm{C}$

The curves of cement stone of NC, R20, and R20F15 samples heated to $800{ }^{\circ} \mathrm{C}$ are shown in Fig. 7 . At $800{ }^{\circ} \mathrm{C}$, the diffraction peak of $\mathrm{Ca}(\mathrm{OH})_{2}$ cannot be observed in the figure because of the decomposition of $\mathrm{Ca}(\mathrm{OH})_{2}$. The characteristic diffraction peak intensities of $3 \mathrm{CaO} \cdot \mathrm{SiO}_{2}$ and $2 \mathrm{CaO} \cdot \mathrm{SiO}_{2}$ of mixed RHA concrete are lower than those of NC. This is because the active $\mathrm{SiO}_{2}$ from $\mathrm{RHA}$ and the hydration product of cement, $\mathrm{Ca}(\mathrm{OH})_{2}$, react with each other and promote cement hydration. Therefore, the compressive strength of RHA concrete is higher than that of NC.

\subsection{Change in microstructure of concrete at high temperatures}

The SEM images of the cement stone of NC at room temperature are shown in Fig. 8(a). A needle mesh structure can be observed from the figure at room temperature, and the pore-structure gradation is relatively poor. The concrete structure is non-densified. Meanwhile, there is a greater amount of calcium hydroxide and ettringite. At $200{ }^{\circ} \mathrm{C}$, the free water of cement and the water of capillary pores escaped, generating more $\mathrm{C}-\mathrm{S}-\mathrm{H}$ gel, which promot-

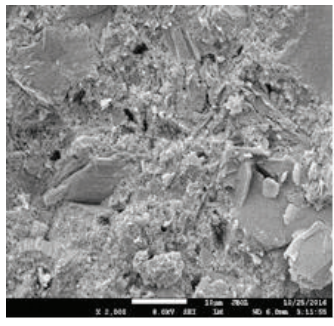

(a) $20^{\circ} \mathrm{C}$

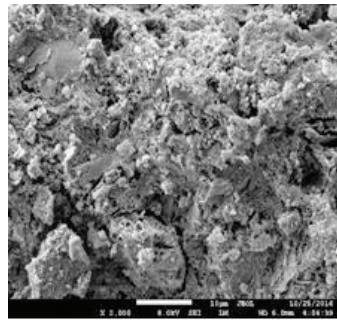

(b) $200{ }^{\circ} \mathrm{C}$

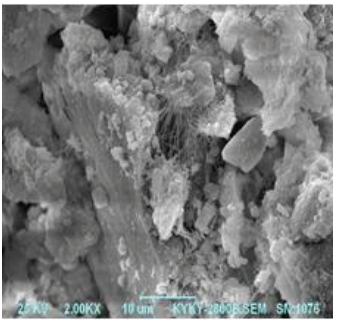

(c) $400{ }^{\circ} \mathrm{C}$

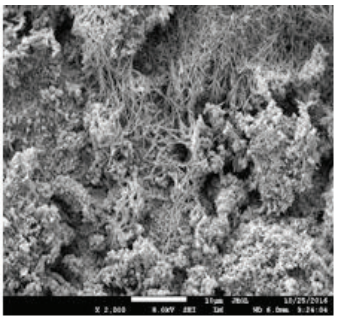

(d) $600{ }^{\circ} \mathrm{C}$

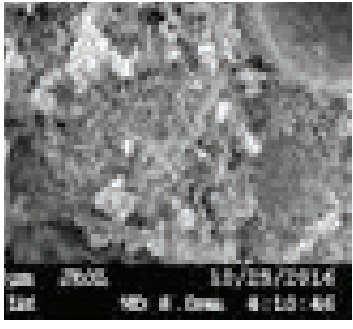

(e) $800{ }^{\circ} \mathrm{C}$

Fig. 8 - SEM micrographs of NC concrete cement after high-temperature treatment $(2000 \times)$ 


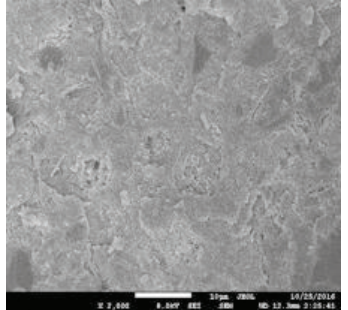

(a) $20{ }^{\circ} \mathrm{C}$

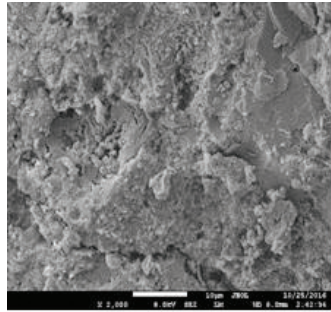

(b) $200{ }^{\circ} \mathrm{C}$

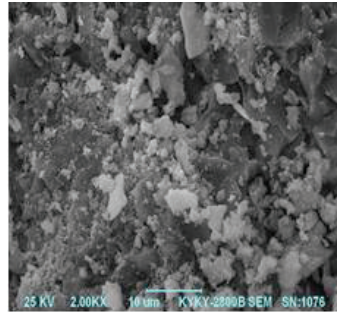

(c) $400{ }^{\circ} \mathrm{C}$

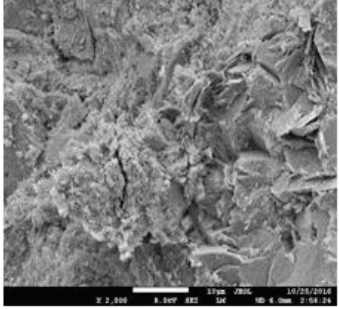

(d) $600{ }^{\circ} \mathrm{C}$

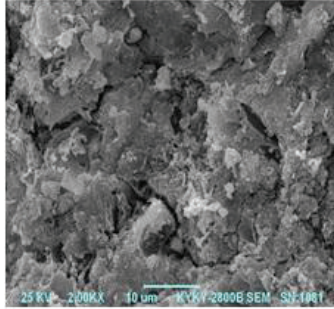

(e) $800{ }^{\circ} \mathrm{C}$

Fig. 9 - SEM micrographs of R20 concrete cement after high-temperature treatment $(2000 \times)$

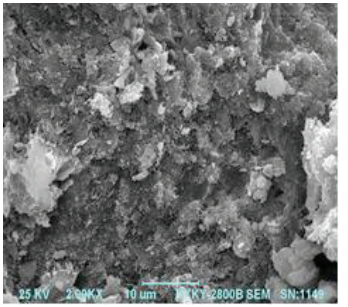

(a) $20^{\circ} \mathrm{C}$

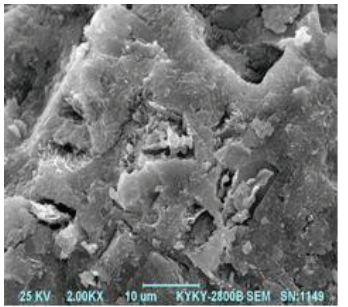

(b) $200{ }^{\circ} \mathrm{C}$

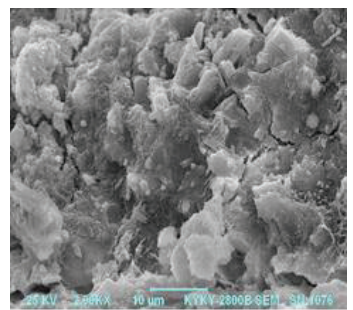

(c) $400{ }^{\circ} \mathrm{C}$

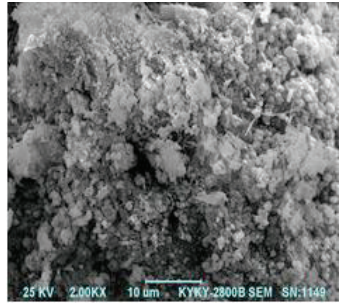

(d) $600{ }^{\circ} \mathrm{C}$

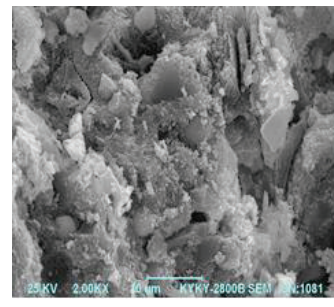

(e) $800{ }^{\circ} \mathrm{C}$

Fig. 10 - SEM micrographs of R20F15 concrete cement after high-temperature treatment $(2000 \times)$

ed the hydration reaction of cement, and made the structure of concrete more compact than that at room temperature. At $400{ }^{\circ} \mathrm{C}$, cracks appear on the surface of concrete, as shown in Fig. 8(C), and the structure is not as compact as at $200{ }^{\circ} \mathrm{C}$. At $600{ }^{\circ} \mathrm{C}$, the hydration product starts losing combined water. Fig. 8(d) shows that many holes and cracks appear in the cement stone. At $800{ }^{\circ} \mathrm{C}$, the crystal water is completely lost, and unhydrated particles in cement and the quartz component of the aggregate react to crystallize. Accompanied by huge expansion, cracks are formed within the aggregate, and the C-S-H gel is incomplete. Meanwhile, the internal structure of the concrete becomes loose, and the strength decreases sharply.

SEM micrographs of R20 concrete cement after high-temperature treatment are shown in Fig. 9. The concrete with $20 \%$ cement replaced by RHA is more compact than NC at room temperature. This is mainly because of the active $\mathrm{SiO}_{2}$ of $\mathrm{RHA}$, which reacts with $\mathrm{Ca}(\mathrm{OH})_{2}$ to produce a greater amount of $\mathrm{C}-\mathrm{S}-\mathrm{H}$ gel. The unhydrated RHA can fill the pore structure, making the concrete more compact. When a part of cement is replaced by RHA, the internal structure of concrete changes with temperature, which is similar to the trend observed in NC. However, the strengths are higher in RHA concrete, and its structure is more compact than that of $\mathrm{NC}$ after high-temperature treatment.

SEM micrographs of R20F15 concrete cement after high-temperature treatment are shown in Fig. 10. The concrete with $35 \%$ cement replaced by $20 \%$ RHA and $15 \%$ FA by mass is more compact than NC at room temperature. This is because the pozzolanic reaction of RHA and FA consumes $\mathrm{Ca}(\mathrm{OH})_{2}$, which improves the microstructure of concrete. The internal structure of concrete is not compact at $200{ }^{\circ} \mathrm{C}$ compared to that at $20^{\circ} \mathrm{C}$. This is mainly due to the lower content of unhydrated cement with greater RHA/FA replacement. As mentioned previously, the microstructural damage of concrete occurs at $200{ }^{\circ} \mathrm{C}$. Above $400{ }^{\circ} \mathrm{C}$, the internal structure of concrete changes with temperature, which is similar to the trend observed in $\mathrm{NC}$ and R20.

\section{Conclusions}

We experimentally investigated the mechanical properties and internal microstructures of concrete at five different temperatures. The following conclusions are drawn from the experimental results.

(1) At room temperature, the compressive strength of RHA concrete is higher than that of $\mathrm{NC}$, and its structure is more compact. With the increase in temperature, the trends of the compressive-strength change are slightly different. At $400{ }^{\circ} \mathrm{C}$, the compressive strength changes slightly. Above $400{ }^{\circ} \mathrm{C}$, it decreases sharply. When heated to $800{ }^{\circ} \mathrm{C}$, the compressive strengths of the specimens are $30 \%-40 \%$ of those at room temperature. Single-mixed RHA and compound-mixed RHA/FA improve the compressive strength of concrete to different degrees after high-temperature treatment. However, the residual compressive strength of R20 is the highest, and it is $50 \%$ higher than that of NC.

(2) The active $\mathrm{SiO}_{2}$ from RHA and the hydration product of cement, $\mathrm{Ca}(\mathrm{OH})_{2}$, react with each other and promote cement hydration and generate the $\mathrm{C}-\mathrm{S}$ - $\mathrm{H}$ gel. Meanwhile, different sizes of unhydrated RHA particles show a good grading effect, filling the pore structure and making concrete denser, in turn increasing the strength of concrete.

(3) The structure of C-S-H gel in concrete is complete at room temperature, and it forms a staggered mesh struc- 
ture. The structure of RHA concrete is more compact than that of NC at room temperature with a lower density of pores.

(4) After the high-temperature treatment, the internal structure of concrete changes. The changes in the structure of RHA and RHA/FA concrete are similar to those of NC. At $200{ }^{\circ} \mathrm{C}$, the free water of cement and the water of capillary pores escape, promoting the hydration reaction of cement and making the structure of concrete more compact than that at room temperature. However, the structure of RHA/FA concrete is less compact than that at room temperature. Above $200{ }^{\circ} \mathrm{C}$, the $\mathrm{C}$-S-H gel decomposes, and the structure of concrete remains incomplete. Meanwhile, $\mathrm{CaCO}_{3}$ decomposition occurs, and $\mathrm{Ca}(\mathrm{OH})_{2}$ breaks down gradually. Therefore, the internal structure of the concrete becomes loose. An increasing number of cracks between the aggregate and the cement paste are observed, which decreases the strength. Compared to NC, the internal structure of RHA concrete is more compact than that of $\mathrm{NC}$ after high-temperature treatment.

\section{Summary}

This paper introduces the mechanical properties and internal microstructures of rice husk ash (RHA) concrete at five different temperatures and with different compositions. The phase composition and microstructure of cement at different temperatures were examined using differential scanning calorimetry/thermogravimetric analysis, X-ray diffraction, and scanning electron microscopy. The results indicate that, at room temperature, the compressive strength of RHA concrete is higher with a more densified structure compared to that of normal concrete; the compressive strength of single-mixed RHA concrete increased slightly with increasing RHA content, whereas that of concrete containing RHA mixed with fly ash decreased with increasing RHA content. When cement was heated at $400{ }^{\circ} \mathrm{C}-800{ }^{\circ} \mathrm{C}$, the compressive strength decreased continuously because of the decomposition of $\mathrm{CaCO}_{3}$. At $800{ }^{\circ} \mathrm{C}$, the compressive strengths are $30 \%-40 \%$ of those at room temperature, and the concrete structure is loose. We found that the compressive strength of concrete with $20 \%$ cement replaced by RHA is $50 \%$ greater than that of normal concrete. The results of this study will be useful in the application of RHA to develop high-performance concrete.

\section{ACKNOWLEDGEMENTS}

The authors are grateful to the National Natural Science Foundation of China (51368049) and the Yinchuan Energy Institute (2016-KY-Z-13) for funding and support.

\section{List of abbreviations and symbols}

$$
\begin{array}{ll}
\mathrm{C} & \text { - cement } \\
\mathrm{C}_{2} \mathrm{~S} & \text { - dicalcium silicate, } 2 \mathrm{CaO} \cdot \mathrm{SiO}_{2}
\end{array}
$$

$$
\begin{array}{ll}
\mathrm{C}_{3} \mathrm{~A} & \text { - tricalcium aluminate, } 3 \mathrm{CaO} \cdot \mathrm{Al} 2 \mathrm{O} 3 \\
\mathrm{C}_{3} \mathrm{~S} & - \text { tricalcium silicate, } 3 \mathrm{CaO} \cdot \mathrm{SiO}_{2} \\
\mathrm{C}_{4} \mathrm{AF} & - \text { calcium aluminoferrite, } 2 \mathrm{CaO} \cdot x \mathrm{Al}_{2} \mathrm{O}_{3} \cdot(1-x) \mathrm{Fe}_{2} \mathrm{O}_{3} \\
\mathrm{C}-\mathrm{S}-\mathrm{H} & - \text { calcium silicate hydrate } \\
\mathrm{DSC} & - \text { differential scanning calorimetry } \\
\mathrm{FA} & - \text { fly ash } \\
\mathrm{HPC} & - \text { high-performance concrete } \\
\mathrm{NC} & - \text { normal concrete } \\
\mathrm{RHA} & - \text { rice husk ash } \\
\mathrm{SEM} & - \text { scanning electron microscopy } \\
\mathrm{SF} & - \text { silica fume } \\
\mathrm{SP} & - \text { superplasticizer } \\
\text { TG } & - \text { thermogravimetric analysis } \\
\text { XRD } & - \text { X-ray diffraction } \\
d & - \text { spacing between the planes in the lattice, } \mathrm{nm} \\
\theta & - \text { diffraction angle, } \\
W & - \text { mass fraction, } \% \\
W
\end{array}
$$

\section{References \\ Literatura}

1. H. Wang, W. T. Chen, C. L. Chen, Silica fume on the strength of high strength concrete test study of the influence of concrete, Concrete 7 (2011) 74-76.

2. B. Han, Y. X. Liu, Rice husk ash preparation and microstructure properties, Sichuan Build. Mater. 6 (2010) 1-2.

3. Q. J. Yu, S. Y. Zhao, Q. G. Feng, High activity of rice husk ash preparation and its effect on the performance of cement, J. Wuhan Univ. Technol. 25 (2003) 15-18.

4. J. Q. Li, H. S. Xu, H. B. Xie, G. Z. Li, Study on the microstructure of silica fume modified cement / lime mortar, Bulletin Chinese Ceramic Soc. 25 (2006) 66-70.

5. H. T. Le, M. H. Ludwig, Effect of rice husk ash and other mineral admixtures on properties ofself-compacting high performance concrete, Mater. Design 89 (2016) 156-166, doi: https://doi.org/10.1016/j.matdes.2015.09.120.

6. C. L. Hwang, B. L. A. Tuan, C.-T. Chen, Effect of rice husk ash on the strength and durability characteristics of concrete, Constr. Building Mater. 25 (2011) 3768-3772, doi: https:// doi.org/10.1016/j.conbuildmat.2011.04.009.

7. B. Chatveera, P. Lertwattanaruk, Durability of conventional concretes containing black rice husk ash, J. Environ. Manage. 92 (2011) 59-66, doi: https://doi.org/10.1016/j.jenvman.2010.08.007.

8. D. Chopra, R. Siddique, Kunal, Strength, permeability and microstructure of self-compacting concrete containing rice husk ash, Biosys. Eng. 130 (2015) 72-80, doi: https://doi. org/10.1016/j.biosystemseng.2014.12.005.

9. Q. G. Feng, Y. Yang, Z. F. Tong, S. Yamamichi, Freezing and thawing resistance of concrete incorporating highly active rice husk ash, J. Chinese Ceram. Soc. 36 (2008) 136139, url: http://en.cnki.com.cn/Article_en/CJFDTOTAL-GXYB2008S1031.htm.

10. S. D. Wang, K. L. Scrivener, Hydration products of alkali activated slag cement, Cement Concrete Res. 25 (1995) 561571, doi: https://doi.org/10.1016/0008-8846(95)00045-E. 
11. N. Puthipad, M. Ouchi, S. Rath, A. Attachaiyawuth, Enhancement in self-compactability and stability in volume of entrained air in self-compacting concrete with high volume fly ash Constr. Building Mater.128 (2016) 349-360, doi: https://doi.org/10.1016/j.conbuildmat.2016.10.087.

12. H. A. Alaka, L. O. Oyedele, High volume fly ash concrete: The practical impact of using superabundant dose of high range water reducer, J. Build. Eng. 8 (2016) 81-90, doi: https://doi.org/10.1016/j.jobe.2016.09.008.

13. Y. B. Ahn, J. G. Jang, H. K. Lee, Mechanical properties of lightweight concrete made with coal ashes after expo- sure to elevated temperatures, Cement Concrete Comp. 72 (2016) 27-38, doi: https://doi.org/10.1016/j.cemconcomp.2016.05.028.

14. B. Fu, C. H. Yang, J. X. Ye, Z. Y. Chen, J. S. Cao, Microstructure and Mechanical Properties of Alkali-activated Slag Cement Pastes Subjected to Temperatures, J. Hunan University (Natural Sci.) 40 (2013) 90-96.

15. M. Sonebi, P. J. M. Bartos, Filling ability and plastic settlement of self-compacting concrete, Mater. Struct. 35 (2002) 462-469, doi: https://doi.org/10.1007/BF02483133.

\section{SAŽETAK}

\section{Utjecaj pepela rižinih ljuski na visokotemperaturna mehanička svojstva i mikrostrukturu betona

\author{
Weihong Wang, a,b Yunfang Meng ${ }^{a, b^{*}}$ i Dezhi Wang ${ }^{a}$
}

Istražen je utjecaj pepela rižinih ljuski (RHA) na čvrstoću i toplinsku otpornost betona. Uz stalan udio veziva, različite količine cementa u betonu zamijenjene su pepelom rižinih ljuski i lebdećim pepelom (FA). Pri različitim temperaturama ispitana je tlačna čvrstoća i toplinska otpornost. Umješavanjem odgovarajuće količine RHA u beton može se povećati njegova tlačna čvrstoća. Pri $800{ }^{\circ} \mathrm{C}$ čvrstoća je veća $50 \%$ od čvrstoće običnog betona.

\section{Ključne riječi}

Pepeo rižinih ljuski, beton, tlačna čvrstoća, visoka temperatura

a School of Civil Engineering and Hydraulic Engineering, Ningxia University, Yinchuan 750 021, Ningxia, Kina

b Yinchuan Energy Institute, Yinchuan 750 105, Ningxia, Kina
Prethodno priopćenje Prispjelo 22. prosinca 2016. Prihvaćeno 18. veljače 2017. 